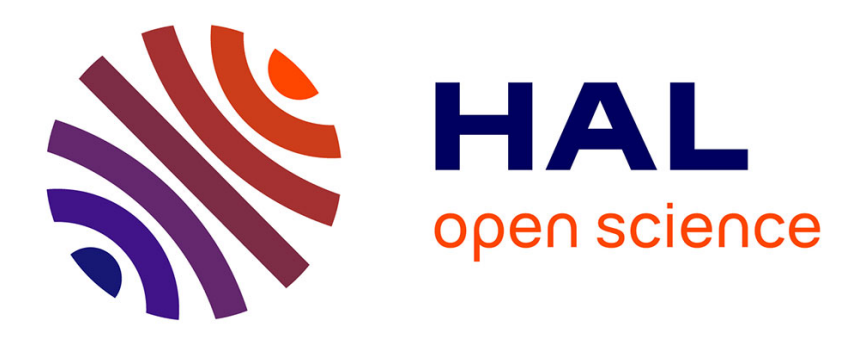

\title{
A Study of Phase Transitions in Sr2FeVO6- $\delta$ by X-Ray Diffraction
}

\author{
A. Maryanowska, J. Pietrzak
}

\section{To cite this version:}

A. Maryanowska, J. Pietrzak. A Study of Phase Transitions in Sr2FeVO6- $\delta$ by X-Ray Diffraction. Journal de Physique IV Proceedings, 1997, 07 (C1), pp.C1-369-C1-370. 10.1051/jp4:19971151 . jpa00254796

\section{HAL Id: jpa-00254796 https://hal.science/jpa-00254796}

Submitted on 1 Jan 1997

HAL is a multi-disciplinary open access archive for the deposit and dissemination of scientific research documents, whether they are published or not. The documents may come from teaching and research institutions in France or abroad, or from public or private research centers.
L'archive ouverte pluridisciplinaire HAL, est destinée au dépôt et à la diffusion de documents scientifiques de niveau recherche, publiés ou non, émanant des établissements d'enseignement et de recherche français ou étrangers, des laboratoires publics ou privés. 


\title{
A Study of Phase Transitions in $\mathrm{Sr}_{2} \mathrm{FeVO}_{6-\delta}$ by X-Ray Diffraction
}

\author{
A. Maryanowska and J. Pietrzak \\ Institute of Physics, A. Mickiewicz University, Umultowska 85, 61-614 Poznah, Poland
}

\begin{abstract}
The thermal expansion of $\mathrm{Sr}_{2} \mathrm{FeVO}_{5.6}(\mathrm{SFVO})$ bas been measured in the temperature interval $20-300 \mathrm{~K}$ by the powder $\mathrm{X}$-ray diffraction technique to elucidate the relationship between the crystal symmetry and its magnetic behaviour. The thermal expansion coefficients $\alpha_{a}, \alpha_{b}$ and $\alpha_{c}$ revealed a sudden decrease at $80 \mathrm{~K}$ and $240 \mathrm{~K}$, although the crystal symmetry of the compound remained unchanged. Moreover, for $100 \mathrm{~K}<\mathrm{T}<240 \mathrm{~K}$ as well as $\mathrm{T}>270 \mathrm{~K}$, a high anisotropy of the thermal expansion was observed. This effect is expected to be related to changes in the magnetic ordering of the compound studied [1].
\end{abstract}

\section{INTRODUCTION}

Compounds with a perovskite crystal structure $\mathrm{ABO}_{3}$ have been investigated especially in view of the ferroelectric properties that they commonly exhibit. For several years "mixed valency" perovskite, described by the formula $\mathrm{A}_{2}\left(\mathrm{BB}^{\prime}\right) \mathrm{O}_{6}$ have been known to exhibit ferroelectric properties with magnetic ordering [2-7]. However, extensive data on the relationship between the crystal symmetry and magnetic properties in these compounds are not available. In this work we have complemented the available in the information on the magnetic properties of SFVO by the results of X-ray diffraction studies.

\section{EXPERIMENTAL}

The method of preparation of SFVO single crystals has been described elsewhere [8]. Chemical analysis and XPS measurements revealed that our crystals of SFVO were homogeneous and of proper stoichiometry.

The crystallographic system of SFVO was resolved on the basis of X-ray diffraction data on powdered monocrystals, at two temperatures $10 \mathrm{~K}$ and $300 \mathrm{~K}$. Moreover, the temperature changes of its lattice parameters were observed. Measurements were carried out on a DRON-2 type diffractometer ( $\mathrm{K}_{\alpha} \mathrm{Fe}$ radiation, $20 \mathrm{~mA}, 35 \mathrm{kV}$ ) equipped with an automatic system enabling scanning of each profile. At a given point the pulses were counted for 10 or 20 seconds, depending on the line intensity and then the pulse counter was moved with a step of $0.01^{\circ}$. The temperature measurements were performed in the range $20 \mathrm{~K}-300 \mathrm{~K}$ with the temperature stabilization to within $\pm 1 \mathrm{~K}$. Temperature changes of the lattice parameters were determined on the basis of the positions of maxima of the profiles : (200), $(020)$, (002). Each profile contained close lines but the applied method of fast recording of the lines permitted accurate determination of the profile maximum.

\section{RESULTS AND DISCUSSION}

The unit cell parameters were determined from 10 reflection observed for SFVO at $10 \mathrm{~K}$ and $300 \mathrm{~K}$ All the reflections at both temperatures considered are indicative of the monoclinic system with the parameters: $a=0.7398(2) \mathrm{nm}, b=0.5032(1) \mathrm{nm}$, $c=0.5421(1) \mathrm{nm}, \beta=95^{\circ} 50.1^{\prime}$ at $10 \mathrm{~K}$ and $a=0.7415(2) \mathrm{nm}, b=0.5037(1) \mathrm{nm}, c=0.5426(1) \mathrm{nm}, \beta=95^{\circ} 54.5^{\prime}$ at $300 \mathrm{~K}$, respectively. The values of the lattice parameters determined at $300 \mathrm{~K}$ are in good agreement with those obtained for single crystals of SFVO [8] at the same temperature. Fig. 1 shows the temperature dependence of the lattice parameters for SFVO. This dependence indicates a multiple transition at $80 \mathrm{~K}$, and at about $240 \mathrm{~K}$ a sudden decrease in the volume of this compound, however, the crystal symmetry remaines unchanged. 


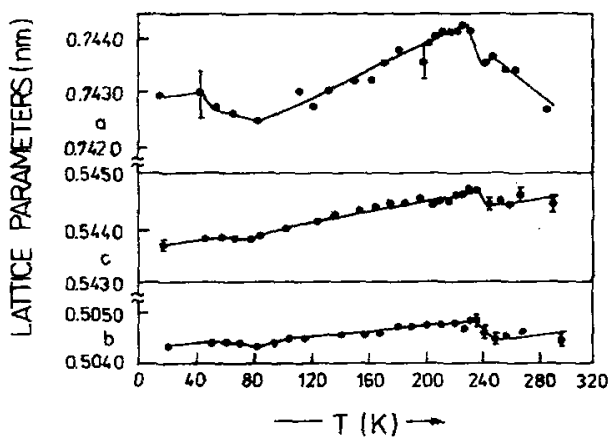

Figure 1: Temperature dependence of the lattice parameters for $\mathrm{Sr}_{2} \mathrm{FeVO}_{5.6}$.

Table I lists the anisotropic thermal expansion values of $\alpha_{1}$ and $\alpha_{\mathrm{y}}$ of SFVO for various of temperature.

Table I. Thermal expansion coefficients $\alpha_{1} 10^{6}\left[\mathrm{~K}^{-1}\right]$ and $\alpha_{v} 10^{6}\left[\mathrm{~K}^{-1}\right]$ of $\mathrm{Sr}_{2} \mathrm{FeVO}_{5.6}$

\begin{tabular}{|cccccc|}
\hline $\begin{array}{c}\text { Temperature } \\
\text { ranges [K] }\end{array}$ & $\alpha_{a}$ & $\alpha_{b}$ & $\alpha_{c}$ & $\left\langle\alpha_{i}\right\rangle$ & $\left.<\alpha_{y}\right\rangle$ \\
\hline$T<50$ & 7.0 & 7.0 & 7.0 & 7.0 & 21.0 \\
$100<T<240$ & 16.6 & 4.6 & 8.5 & 9.9 & 29.7 \\
$240<\mathrm{T}<290$ & -22.2 & 11.2 & 12.0 & 0.33 & 1.0 \\
\hline
\end{tabular}

A comparison of the principal coefficients $\alpha_{a}, \alpha_{b}, \alpha_{c}$ at $T>50 \mathrm{~K}$ shows an increasing anisotropy of expansion. Such as increase in the anisotropy of expansion is possible even for $T>240 \mathrm{~K}$, when the expansion occurs in two directions $(b$ and $c$ ) and contraction in the third direction (a). In the first approximation the coefficients of volume expansions are three times greater than those of linear expansion $\alpha_{v} \approx 3 \alpha_{1}$. The coefficient of volume expansion for SFVO below $240 \mathrm{~K}$ is of the same order as that for $\mathrm{SrTiO}_{3}\left(\alpha=28.310^{-6} \mathrm{~K}-1\right.$; $110 \mathrm{~K}<\mathrm{T}<300 \mathrm{~K})[9]$ and $\mathrm{SrZrO}_{3}\left(\alpha=26.310^{-6} \mathrm{~K}^{-1}, 298 \mathrm{~K}<\mathrm{T}<590 \mathrm{~K}\right)$ [10] in a similar range of temperatures, which for $\mathrm{ABO}$, $\mathrm{perovskites}$ indicates that the influence of the $\mathrm{B}$ cation on the thermal expansion is not negligible. Above the temperature of the magnetic transition $\left(\mathrm{T}_{M}=256 \mathrm{~K}\right)$, the volume expansion of SFVO is very small and has the invar behaviour [11]. An alloy of $34 \% \mathrm{Ni}-\mathrm{Fe}$ (invar) is characterized by a very small coefficient of expansion $\alpha \subseteq 1 * 10^{-6} \mathrm{~K}^{-1}[11]$ at $300 \mathrm{~K}$ while Fe and $\mathrm{Ni}$ have $\alpha=11-1210^{-6} \mathrm{~K}^{-1}$ [11]. The anomalous properties of invar are related to the influence of spontaneous magnetostriction compensating the normal Debye thermal expansion. In view of the results obtained we suggested that the perovskite type compound SFVO shoud be regarded as an invar of a new class.

\section{References}

[1] Maryanowska A., Pietrzak J., Zarek W., J.M.M.M. 140-144 (1995) 1581-1582.

[2] Nakagawa T., J. Phys. Soc. Japan 24 (1968) 806-811

[3] Pietrzak J. Maryanowska A. and Leciejewicz J. phys. stat. sol.(a) 65 (1981) K79-82.

[4] Smolenskii G.A. and Chupis I.E., Usp. Fiz. Nauk 137 (1982) 418-448

[5] Howes B. . Pelliuzone M., Fischer P., Taborez-Muñoz C., Rivera J, P. and Schunid H., Ferroelectrics, 54 (1984) $317-320$.

[6] Maryanowska A. and J. Pietrzak, Ferroelectrics, 162 (1994) 81-85.

[7] de Ligny D. and Richet P., Phys. Rev. 53 (1996) 3013-3021.

[8] Maryanowska A. Pietrzak J., Ratajezak-Sitarz M. and Katuski Z., Acta Phys. Pol., A 76 (1989) 97-100.

[9] Lytle F., J. Appl. Phys. 35 (1964) 2212-2215.

[10] Branson D.L., J. Am. Ceram. Soc. 48 (1965) 441-443.

[11] Chikazumi S. J.M.M.M. 15-18 (1980) 1130-1131. 